\title{
Experimental Study of the Ignition Process and Combustion of Biodiesel-water-air Rapid Mixing Derived From Waste Cooking Oil, Crude Palm Oil and Jatropha Oil in Burner Combustion
}

\author{
Mirnah Suardi ${ }^{1, a}$, Norazwan Azman ${ }^{1}$, DahrumSamsudin ${ }^{1}$, S. H. Amirnordin ${ }^{1}$, \\ Norani Mansor ${ }^{1}$, Amir Khalid ${ }^{1, b}$
}

${ }^{1}$ Combustion Research Group (CRG), Centre for Energy and Industrial Environment Studies (CEIES), Universiti Tun Hussein Onn Malaysia, Parit Raja, Batu Pahat, 86400 Johor, Malaysia. amirnahsuardi@yahoo.com, bamirk@uthm.edu.my

Key Words: Emulsified Biodiesel, Renewable fuel, Rapid Mixing, Mixture Formation, Combustion Process, Emissions, Flame

\begin{abstract}
The prospects of fossil oil resources and strengthen of future emission regulation have raised keen attention together with the issue of renewable alternative fuel. As one of the different solutions to these problems, emulsion fuel technology in biodiesel has received close attention because it may provide better combustion efficiency and would contribute to a reduction in emissions, such as nitrogen oxides $\left(\mathrm{NO}_{\mathrm{x}}\right)$ or particulate matter $(\mathrm{PM})$. The solution of this issue is by using Biodiesel fuel as an alternative fuel from waste cooking oil (WCO), crude palm oil (CPO) and Jatropha Oil (JPO). In addition, Waste cooking oil is one of the most economical options for producing biodiesel due to the biodegradable properties and preserves energy. This study focuses on the observation of ignition and combustion characteristics of biodiesel-water-air rapid mixing of biodegradable fuel using internally rapid mixing injector in burner combustion. In this research, the relation of mixture formation, burning process and flame development of biodiesel were investigated in detail. The parameters include equivalent ratio, water content and mixture formation are studied. The flame development is analyzed in term of flame longest for testing. The result shows that equivalent ratio and water content affect the combustion. Increasingly of water content will reduce the flame length and increase the probability of misfire.
\end{abstract}

\section{Introduction}

Environmental concerns and the rising cost of fossil fuels such as diesel resulting in research on alternative fuels such as biodiesel have a charm of its own. Renewable fuels such as biodiesel continues to be of interest to achieve a sustainable energy economy, thus reducing dependence on fossil fuels. It is noted that the use of transportation fuels that are renewable and its use is increasing, particularly in Malaysia. Biodiesel is an environmentally friendly fuel that is clean and is a source of energy that can be renewed. It is usually made from animal fat or vegetable oil revenue trans-esterification reaction. The oxygen content in biodiesel is $11 \%-15 \%$, increased combustion process and reduces emissions from diesel engines [1]. The use of biodiesel is very good because it can help reduce the emission of harmful gases such as sulphur dioxide (S), carbon monoxide (CO) and hydrocarbons (HC). However, the percent of nitrogen oxide emissions (N) are very high compared to diesel fuel. This is because nitrogen oxide $(\mathrm{N})$ is closely related to the concentration of oxygen in biodiesel fuel. In terms of the combustion process, the biodiesel is able to produce a complete combustion process compared to diesel fuel [2][4].

\section{Experimental setup}

Biodiesel blend starts from B5 to B15using the blending machine. The purified Crude Palm Oil (CPO) and Waste Cooking Oil (WCO) were then blended with diesel in various concentrations for preparing a biodiesel blend. During blending process, the mixture was stirred at $70^{\circ} \mathrm{C}$ for 1 hour. The rotating blade speed was adjusted to maintain the speed at 270 RPM. 


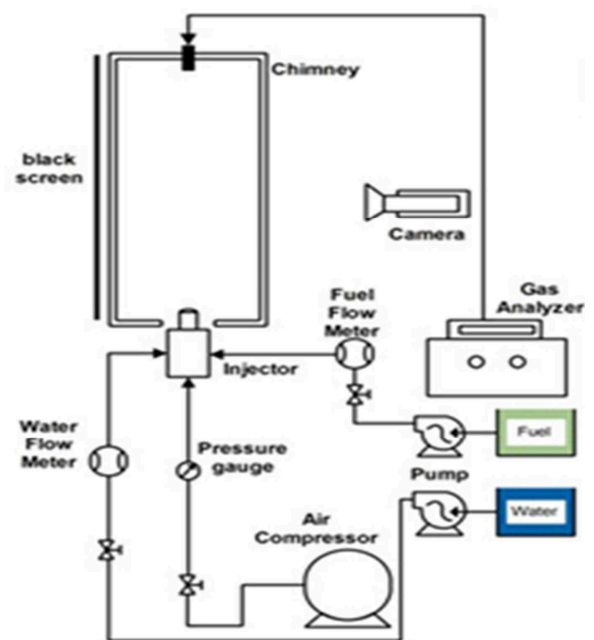

Figure 1: Schematic Diagram of experimental setup

Table 2: Properties of WCO

\begin{tabular}{|l|c|}
\hline Parameter & Value \\
\hline Viscosity at $40{ }^{\circ} \mathrm{C}(\mathrm{mm} 2 / \mathrm{s})$ & 47.66 \\
\hline Volume $(\mathrm{kg} / \mathrm{m} 3)$ at $15^{\circ} \mathrm{C}$ & 903 \\
\hline Flash Point $\left({ }^{\circ} \mathrm{C}\right)$ & 310 \\
\hline Free Fatty Acid $(\%)$ & 1.6 \\
\hline Acid Number $(\mathrm{mg} \mathrm{KOH} / \mathrm{g}$ Oil) & 3.2 \\
\hline Saponification Value $(\mathrm{mg} \mathrm{KOH} / \mathrm{g}$ Oil $)$ & 182 \\
\hline Water Content $(\%)$ & 0.6 \\
\hline
\end{tabular}

Table 1: Properties of $\mathrm{CPO}$ at ambient temperature $\left(45^{\circ} \mathrm{C}\right)$

\begin{tabular}{|c|c|c|c|c|}
\hline \multirow{2}{*}{ Fuel Type } & \multicolumn{4}{|c|}{ Properties } \\
\cline { 2 - 5 } & Density $\left(\mathrm{g} / \mathrm{cm}^{3}\right)$ & $\begin{array}{c}\text { Kinematic Viscosity } \\
(\mathrm{CP})\end{array}$ & Flashpoint ${ }^{(\mathrm{C})}$ & $\begin{array}{c}\text { Water Content } \\
(\mathrm{ppm})\end{array}$ \\
\hline STD & 0.833736 & 3 & 80 & 79.6 \\
\hline B5 & 0.837048 & 3 & 91.5 & 120.1 \\
\hline B10 & 0.837664 & 2.9 & 92 & 158.6 \\
\hline B15 & 0.840428 & 3 & 93.5 & 219 \\
\hline B20 & 0.841172 & 3.1 & 94.5 & 294.7 \\
\hline B25 & 0.841716 & 3 & 97 & 363.3 \\
\hline B30 & 0.845852 & 3.2 & 97.5 & 397.1 \\
\hline B35 & 0.844816 & 3.4 & 99.5 & 426.9 \\
\hline B40 & 0.848236 & 3.2 & 100 & 558 \\
\hline
\end{tabular}

Table 3: Properties of JPO

\begin{tabular}{|l|l|l|l|}
\hline Properties & $\begin{array}{l}\text { Crude } \\
\text { Jatropha } \\
\text { oil }\end{array}$ & $\begin{array}{l}\text { Jatropha } \\
\text { biodiesel }\end{array}$ & Diesel \\
\hline Viscosity $\left(\mathrm{mm}^{2} / \mathrm{s}\right)$ & 35.4 & 4.59 & 4.84 \\
\hline Flash point $\left({ }^{\circ} \mathrm{C}\right)$ & 226 & 182 & 71 \\
\hline Fire point $\left({ }^{\circ} \mathrm{C}\right)$ & 236 & 190 & 76 \\
\hline $\begin{array}{l}\text { Gross calorific value } \\
\left(\mathrm{MJ} \mathrm{kg}^{-1}\right)\end{array}$ & 39.76 & 45.2 & 46.22 \\
\hline Density $\left(\mathrm{g} \mathrm{ml}^{-1}\right)$ & 0.94 & 0.88 & 0.83 \\
\hline
\end{tabular}

The injector is equipped with one air compressor and two electrical pumps. Figure 1 shows the setup of the experiment consists of an injector which has 8 holes with a diameter. Air flow rates and fuel flow rates are controlled valve and a voltage regulator respectively. Table 1 and Table 2 are the properties of biodiesel will be used. The distance between the camera and injector is $385.50 \mathrm{~cm}$ and the distance between injector and black screen is $91.5 \mathrm{~cm}$. The experiment starts by injecting the fuel, water and air into the injector. The injector system uses fuel-water-air internal rapid mixing concept. The air is pressurized at 0.35 bar. The fuel flow rate and water flow rate are controlled by flow meter and speed controller. Fuel-water-air is mixed at mixing chamber. Then, the mixtures are sprayed out from the nozzle. The mixtures will be ignited using the burner. The flame image is captured by using Digital Single-Lens Reflex (DSLR) camera of Canon EOS 550D. The experiment is repeated for different equivalent ratio with biodiesel for the water content W0, W5, W10 and W15 respectively. The flame characteristics which include flame length, flame angle and flame area is analyzed.

\section{Result and Discussion}

Figure 2, Figure 3 and Figure 4 shows the spray formation of W0, W5, W10 and W15 in equivalent ratio 0.6 (lean), 1.0 (stoichiometric), and 1.4 (rich). Analyses of spray development are WCO, CPO and JPO. The spray of fuel is sprayed upward from the injector when the supply mixtures are pumped into the injector, as vary with time, the volume of spray increases and it's drawn by the ventilation system. At high equivalent ratio, the spray image becomes clearer due to the increment of the flow rate of the mixtures. This indicates that more fuel is being injected into the injector and the spray contains more fuel compared to the spray of low equivalent ratio. As observed from the images, the penetration length shows an increasing trend with equivalent ratio for each type of water content, while the spray angles remain unchanged. Followed by the increment of equivalent ratio of 0.6 to 1.4 , the color intensity of the spray increases as shown, this indicates that the concentration of biodiesel in the mixture increases. On the other hand, the spray angle is becoming narrower when the water content increase, but it does not give significant effect on the spray area 
since the differences of angle are small. Hence the spray area is affected by the penetration length only.

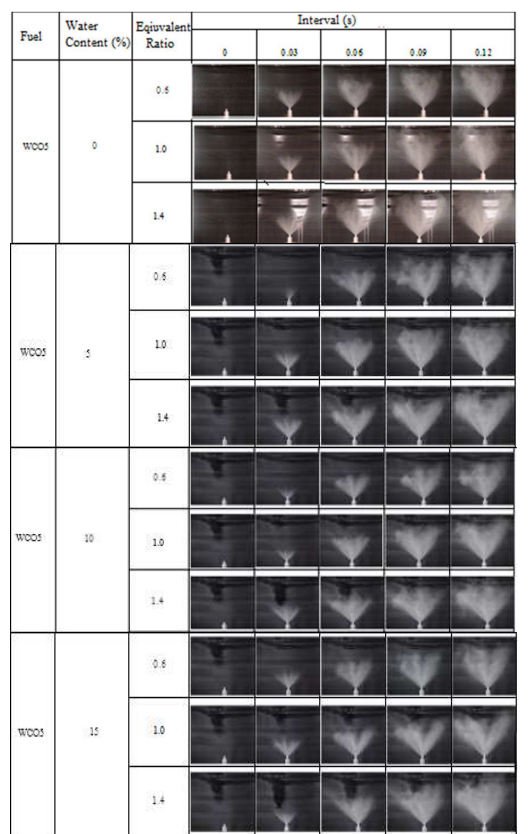

Figure 2: Mixture Formation for Biodiesel from WCO fuel

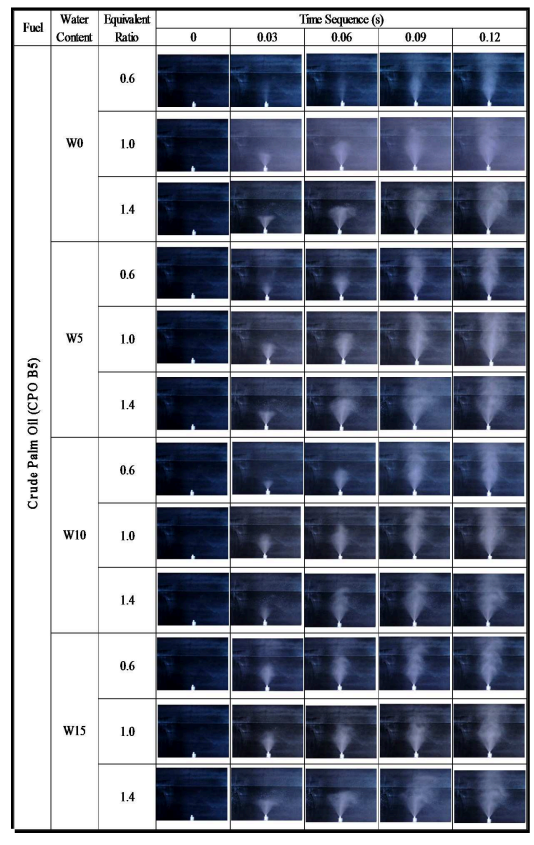

Figure 3: Mixture Formation for Biodiesel from CPO fuel

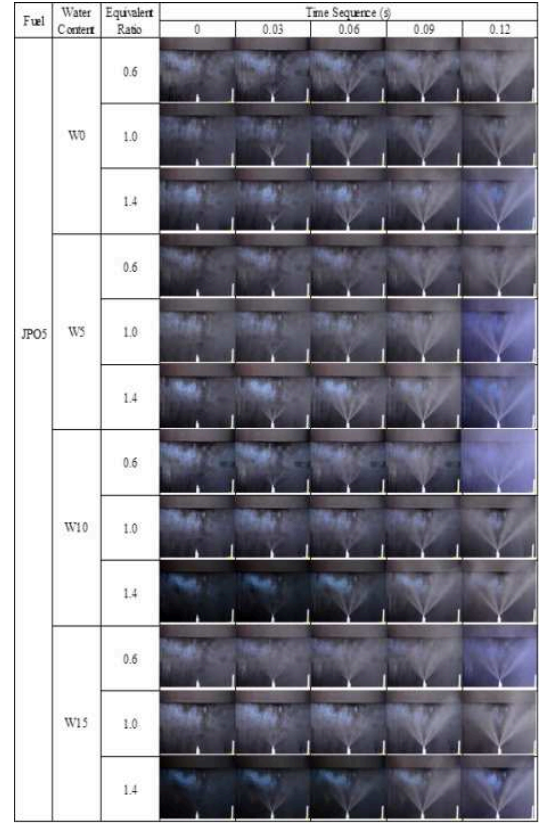

Figure 4: Biodiesel Flame Developement from JPO fuel

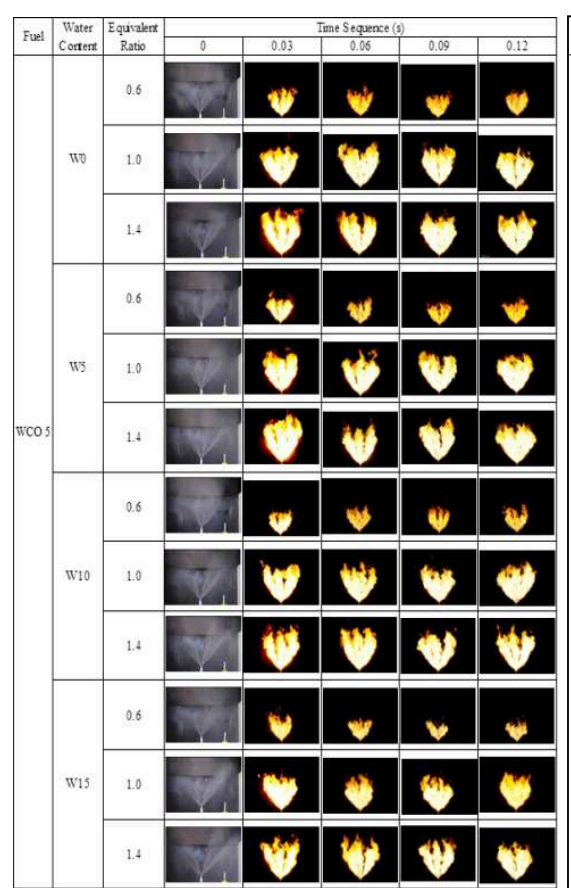

Figure 5: Biodiesel Flame Developement from WCO fuel

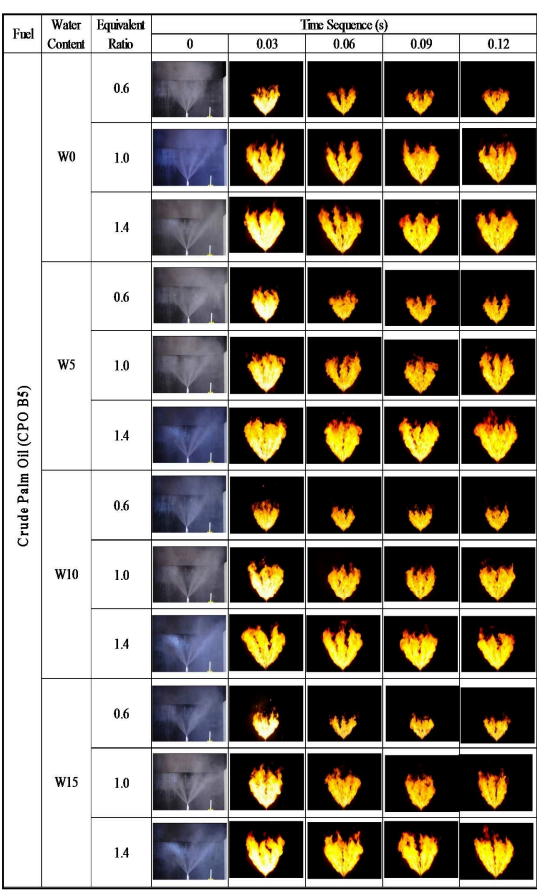

Figure 6: Biodiesel Flame Developement from CPO fuel

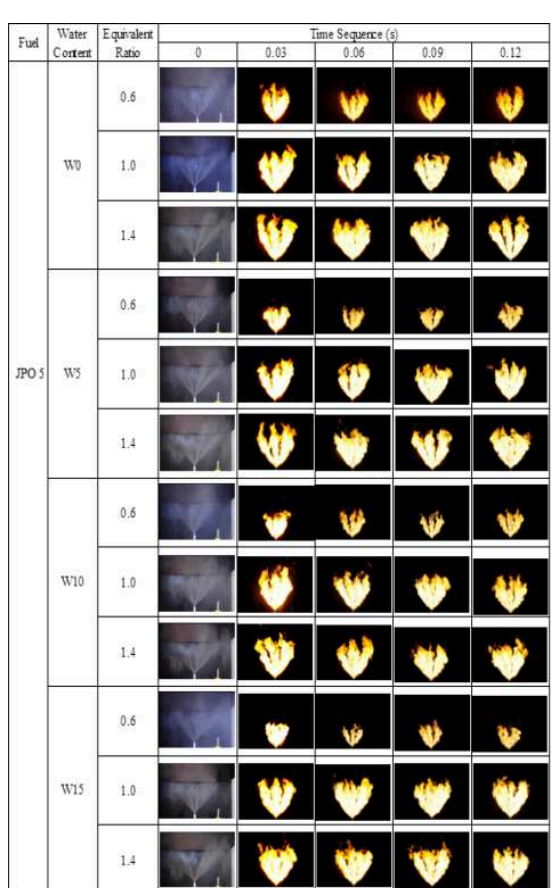

Figure 7: Biodiesel Flame Developement from J PO fuel

Figure 5, Figure 6 and Figure 7 shows the flame developments of biodiesel fuel with different water contents, as can observe from the figure, at an equivalent ratio of 1.0 (stoichiometric), the combustion can occur at this point for all fuel. Other than that, the biodiesel mixed with some water contents seem like having a lower flame height. Moreover, the flame area that produced from an equivalent ratio of 1.4 for all water contents has a larger flame area compared to other equivalent ratio. This is the point where the rich combustion takes place. In addition, at time 0.06 seconds after start of ignition, the flame structure for all fuels and all equivalent ratios seem like to be exploded 
and expand its flame area and then shrinking at 0.09 second and after that becomes constant and developed flame structure.

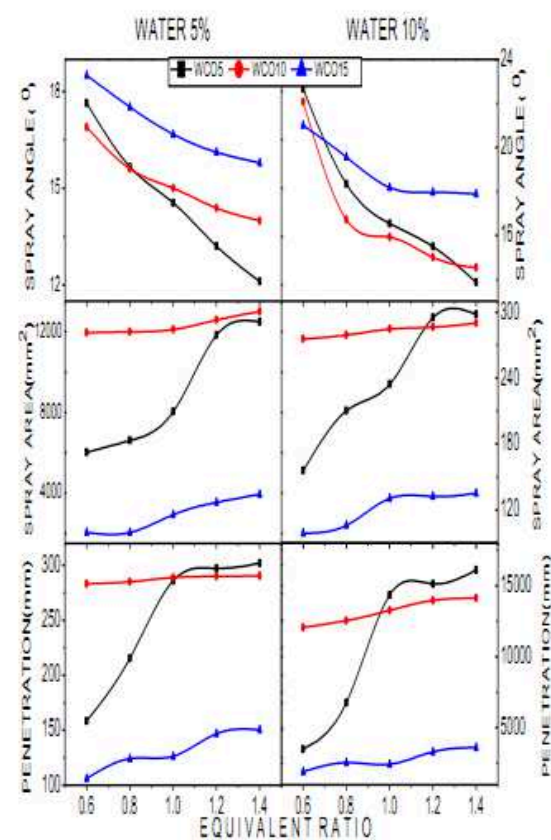

Figure 8: Effect of mixture formation derive from WCO fuel

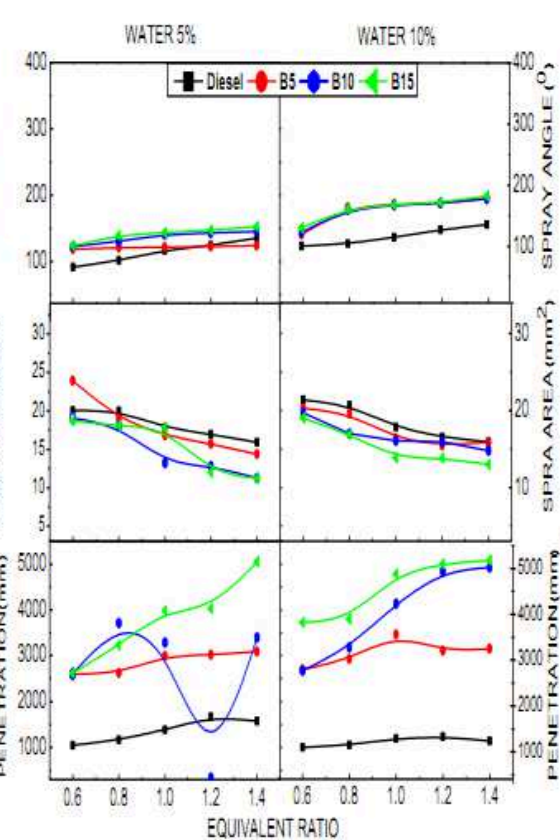

Figure 9: Effect of mixture formation derive from $\mathrm{CPO}$ fuel

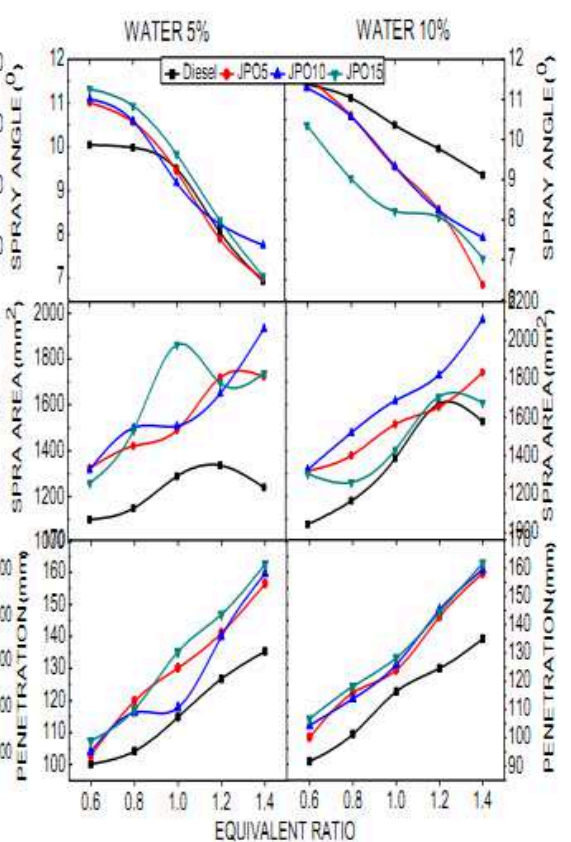

Figure 10: Effect of mixture formation derive from JPO fuel

Figure 8, Figure 9 and Figure10show the graph of mixture formation which is penetration length, spray angle and spray area against equivalent ratio of water content of W0, W5, W10 and W15. From the figure, the penetration length is increasing with the equivalent ratio for different water content. At the same time, W15 has the highest penetration length among other water content, this is due to the viscosity of W15 is the highest, which the penetration length is directly proportional to the viscosity. W0, which is the pure biodiesel fuel, has the lowest penetration length with lowest viscosity. The viscosity of the mixtures is affected by the water content, as the water content of the mixture increases, the viscosity also increase. On the other hand, the spray angles for all condition of water content with increments of equivalent ratio are about the same. However, it shows a decreasing trend when the water content is increasing, which W0 has the largest spray angle and $\mathrm{W} 15$ has the smallest spray angle. Therefore, it proves that the spray angle is inversely proportional to the viscosity as viscosity increase, the spray angle decreases. Furthermore, spray area is a dependent variable which it depends on the penetration length and spray angle. Penetration length will give more effect on the spray area which shows from the result. It can be seen that the spray area of W15 is the largest due to its penetration length is the longest, although its spray angle is small compared to others.

\section{Conclusion}

In this research, a fundamental study on the ignition process and burning process of emulsified biodiesel combustion was carried out using a burner system. It has been changing water content and the equivalent ratio. High water content in the mixtures will result in longer penetration length and smaller spray angle. Penetration length is contributing in spray area, where longer the length will produce the larger area. An equivalent ratio will give effect increase the penetration length as the equivalent ratio increase. In addition, flow rate makes the color intensity of spray increases with the increment of equivalent ratio, more fuel is being injected and hence the concentration of diesel fuel in the mixtures increases. The larger flame area is produced by a higher equivalent ratio, which the spray contains more fuel particles that makes the combustion process easy to take place. 


\section{Acknowledgements}

The author also would like to thank the Ministry of Higher Education, Malaysia for supporting this research under Research Acculturation Grant Scheme (RAGS) Vot. R024 and Exploratory Research Grant Scheme (ERGS) vote. E032

\section{References}

[1] Y. Kidoguchi, T. Yatsufusa, and D. Nakagawa, "Improvement of Emissions and Burning Limits in Burner Combustion using an Injector on the Concept of Fuel-water Internally Rapid Mixing," in European Combustion Meeting, 2011.

[2] Amir Khalid, N.Tamaldin, M. Jaat, M. F. M. Ali, B. Manshoor, Izzuddin Zaman, "Impacts of biodiesel storage duration on fuel properties and emissions", Procedia Engineering, volume 68, 2013, Pages 225 - 230, Elsevier, 2013, DOI: 10.1016/j.proeng.2013.12.172..

[3] T. Yatsufusa, T. Kumura, Y. Nakagawa, and Y. Kidoguchi, "Advantage of Using WaterEmulsified Fuel on Combustion and Emission Characteristics," in European Combustion Meeting, 2009 , pp. 2-7.

[4] Syahrullail, S., Nakanishi, K., Kamitani, S., 2005. Investigation of the effects of frictional constraint with application of palm olein oil lubricant and paraffin mineral oil lubricant on plastic deformation by plane strain extrusion. Japanese Journal of Tribology, Volume 50, Issue 6, Pages 727-738.

[5]Amir Khalid, Norazwan Azman, Hanis Zakaria, B. Manshoor, Izzuddin Zaman, Azwan Sapit, Mutalib Leman, "Effects of storage duration on biodiesel properties derived from waste cooking oil", Applied Mechanics and Materials, Volume 554, 2014, Pages 494-499, DOI: 10.4028/www.scientific.net/AMM.554.494

[6]Amir Khalid, "Effect of Ambient Temperature and Oxygen Concentration on Ignition and Combustion Process of Diesel Spray". Asian Journal of Scientific Research 6(3), pp.434-444, 2013.

[7] W. C. M. Sekaran, "Transient State Fuel Injection - A New Concept with Different Fuel Combinations," in Interdisciplinary Research and Development, 2011, no. June, pp. 461-467.

[8] Hafis, S.M., Ridzuan, M.J.M., Farahana, R.N., Ayob, A., Syahrullail, S., 2013. Paraffinic mineral oil lubrication for cold forward extrusion: Effect of lubricant quantity and friction, Tribology International, Volume 60, Pages 111-115.

[9] Amir Khalid, S. H. Amirnordin, L. Lambosi, B. Manshoor, M. F. Sies, H. Salleh, "Spray Characteristic of Diesel-Water Injector for Burner System", Advanced Materials and Research Vols. 845 (2014), Trans Tech Publications, Switzerland, pp 66-70.

[10]K. Kannan and M. Udayakumar, "NOx and HC Emission Control Using Water Emulsified Diesel in Single Cylinder Diesel Engine," vol. 4, no. 8, pp. 59-62, 2009. .

[11]Amir Khalid, M.D. Anuar, Yusri Ishak, B. Manshoor, Azwan Sapit, Mutalib Leman, Izzuddin Zaman, "Emissions characteristics of small diesel engine fuelled by waste cooking oil", MATEC Web of Conferences, Volume 13, 2014, Article number 06006, DOI: $10.1051 /$ matecconf/20141306006.

[12]Amir Khalid, Keisuke Hayashi, Yoshiyuki Kidoguchi , Tomoaki Yatsufusa, "Effect of air entrainment and oxygen concentration on endothermic and heat recovery process of diesel ignition", (2011) SAE Technical Papers, DOI: 10.4271/2011-01-1834. 